\title{
Decision Support Model for User Submission Approval Energy Partners Candidate Using Profile Matching Method and Analytical Hierarchy Process
}

\author{
Moedjiono $^{1}$, Nia Rahma Kurnianda ${ }^{2}$, Aries Kusdaryono ${ }^{3}$ \\ 1,2,3, Graduate Program, Budi Luhur University, Jakarta \\ 'moedjiono@gmail.com,'nr.kurnianda@gmail.com, 'aries.kusdaryono@gmail.com
}

\begin{abstract}
In the field of services, customer satisfaction is a very important factor and determine the success of an enterprise. In the field of outsourcing, customer satisfaction indicator is the labor required delivery in a timely manner and has a level of quality in accordance with the terms proposed by the customer. To provide the best talent to customers, team recruitment and selection must perform a series of tests with a variety of methods to match the criteria of office given by the user with the criteria owned candidates and in order to support growth in graduation rates force a partner at the stage of user approval. For this purpose, the authors conducted a study with the method of observation, interviews, document reviews the candidate recruitment process, so as to provide recommendations for candidates with the highest quality delivery to the user at the stage of approval. The author put forward a model of decision support that is supported by the method of profile matching and Analytical Hierarchy Process (AHP) in problem solving. The final results of this study can be used to support a decision in order to improve the effectiveness of the delivery of quality candidates, increase customer satisfaction, lower costs and improve gross operational margin of the company.
\end{abstract}

Keywords: Decision Support Model, recruitment, outsourcing, Analytical Hierarchy Process, Profile Matching.

\section{INTRODUCTION}

Customer satisfaction is a very important factor and determine the success of an enterprise. This is supported by the statement of K. Douglas Hoffman and John E.G. Beteson, namely: "costumers without the service firm has no reason to exist" [1]. In the service business, there are many different types of services one of which is in the form of outsourcing services. For services in the field of labor outsourcing, indicators of customer satisfaction with the delivery of labor is needed in a timely manner and has a level of quality in accordance with the terms proposed by the customer. In determining the candidates to be submitted for approval following the manual process of course is a matter that requires precision, patience and sharpness. But along with the increasing number of jobs offered by the customer, the more the candidates come with a variety of skills, backgrounds and disciplines. This condition can affect less suitability of candidates provided from the customer's criteria. The discrepancy may be negatively affected customer satisfaction. The process of defining a match to bring 
the customer's criteria and qualifications of prospective employees become more complex and so we need the help of a model to simplify the process. Based on the foregoing, the author intends to do research. Results from these studies can support decisions in the process of selection of candidates recommended to the customer to be included in the manual approval process.

\section{METHODS}

\subsection{Human Resources}

According to Prof. Dr. H. Hadari Nawawi, human understanding is divided into three aspects, namely [2]: people who work and serve as an asset of the organization/company that can count the number, the potential is the driving force of the organization, and creation of Almighty God as the driver of different organizations with resources other power.

\subsection{TELOS Factors \& PDM Strategy}

According to Suryadi Bunawan and D. Suryadi H. S. in the planning stages of information systems, there is a feasibility factor that refers to the possibility of information systems successfully developed and used, and factors relating to support strategic business goals information system which is referred to by TELOS and PDM [3]. TELOS eligibility factors proposed a system must meet the following criteria: technical feasibility, economic feasibility, legal feasibility, operational feasibility, and feasibility of schedule. Factors PDM strategy, in addition to eligibility, a project proposed information system should also support the strategic factors that include: productivity, differentiation, and management.

\subsection{Analytical Hierarchy Process (AHP)}

According to Saaty [4], a hierarchy is defined as a representation of a complex problem in a multi-level structure where the first level is a goal, followed by level factors, criteria, sub-criteria, and so on down to the last level of the alternatives. In developing the AHP there are some basic principles that must be done, namely: making hierarchy, assessment criteria and alternatives, determine priorities, and logical consistency.

\subsection{Unified Modeling Language (UML)}

According to Dennis, Unified Modeling Language (UML) is a standard language for visualization, specification, construction and documentation of the artifacts of a 
software, and can be used for all stages in the system development process from analysis, design to implementation [5].

\subsection{ISO 9126}

Testing the quality of decision support models adopting the test model ISO 9126. The aspects of testing adopted are as follows [6]: functionality, reliability, usability, and efficiency.

\section{RESULTS AND DISCUSSION}

\subsection{Data analysis}

Grouping the data, findings and identification of needs:

a) In the absence of business procedures specific to the candidate ranking system resulting in the delivery of candidates to interview less friendly stage in accordance with the desired needs of the user.

b) Special Ranking of the candidates as the basis for a model requires a comparison. Comparisons include occupational profiles and employee profiles.

c) Profile positions in accordance with the norms of the company or the customer demand of an administrative nature is worth an absolute and valid as the minimum value of graduation candidates to take the opportunity to stage interview user who accounted for a value of $60 \%$ of the total value of three criteria of core intelligence that intellectual, attitude and administrative work. Occupational profiles based on user needs, but not the main aspect as candidates for the capital to carry out its work is divided into three aspects, namely the behavior and properties, physical, and verbal.

In this decision support modeling, decision support components used are:

a) Database containing information related to the transaction data daily process of recruitment and selection of employees consisting of information about applicant data, FPTK, partners, the results of a psychological test, function, outcome walk in interview, schedule user interviews, the results of user interviews and implementing activities selection.

b) Knowledge Based Subsystem:

- Norma results of psychological tests: the provisions of the lower limit of the norm results of psychological tests aspects of intellectual acumen of the company is 3 to functions other than the office boy and security as well as for the provision of the lower limit of the results of psychological tests work attitude of the company is one of the standard unless there is a particular demand value to 3 . 
- Results walk in interview administrative Knowledge: that fall into the category of benefit is education, majors, GPA and work experience. In the assessment of benefit categories can be assumed the higher its value is increasingly recommended. Converting the value used in giving a score to the sub-criteria of education and departments which are non-numerical data is.

Of the applicants who come there are three people who applied to be a technician to the Partner. Having counted and the score obtained, the next step is do a gap analysis between the Employee Profile Position. For sub-aspects will be averaged to get a value Employee Profile per aspect, specifically for the results of fractions will be rounded off in accordance with the rounding, by phasing out as follows:

a) Calculate each prospective employees by using gap analysis, using a prospective employee (candidate applicants) Michael, Retnaningsih, and Rayyan as listed in Table 1, Table 2 and Table 3 as follows:

Table 1. Michael prospective employees gap analysis

\begin{tabular}{llccc}
\hline No & \multicolumn{1}{c}{ Selection Aspect } & $\begin{array}{c}\text { Employee } \\
\text { Profile }\end{array}$ & $\begin{array}{c}\text { Position Gap } \\
\text { Profile }\end{array}$ & Gap \\
\hline 1 & Intelectual Intelligence & 4 & 3 & 1 \\
2 & Work Attitude Aspect & 4 & 3 & 1 \\
3 & Behavior and & & & \\
& Personality & 4 & 3 & 1 \\
4 & Administrative Aspects & 2 & 3 & -1 \\
& & 3 & 3 & 0 \\
& & 0 & 2.75 & -3 \\
& & 21 & 27 & -6 \\
& & 2 & 1 & 0 \\
& & 1 & 2 & 0 \\
& & 2 & 2 & -1 \\
5 & Physical Aspects & 2 & 2 & 0 \\
6 & Verbal Aspects & 3 & 3 & 1 \\
\hline
\end{tabular}

Table 2. Retnaningsih prospective employees gap analysis

\begin{tabular}{llccc}
\hline No & \multicolumn{1}{c}{ Selection Aspects } & $\begin{array}{c}\text { Employeee } \\
\text { Profile }\end{array}$ & $\begin{array}{c}\text { Position } \\
\text { Profile }\end{array}$ & Gap \\
\hline 1 & Intellectual Intelligence & 5 & 3 & 2 \\
2 & Work Attitude Aspects & 4 & 3 & 1 \\
3 & Behavior and Personality & 7 & 3 & 4 \\
\hline
\end{tabular}

Table 3. Rayyan prospective employees gap analysis

\begin{tabular}{llccc}
\hline No & Selection Aspects & $\begin{array}{c}\text { Employeee } \\
\text { Profile }\end{array}$ & $\begin{array}{c}\text { Position } \\
\text { Profile }\end{array}$ & Gap \\
\hline 1 & Intellectual Intelligence & 6 & 3 & 3 \\
2 & Work Attitude Aspects & 5 & 3 & 2 \\
3 & Behavior and Personality & 8 & 3 & 5
\end{tabular}


4 Administrative Aspects

\begin{tabular}{ccc}
3 & 3 & 0 \\
3 & 3 & 0 \\
3,02 & 2,75 & 0 \\
22 & 27 & -5 \\
1 & 1 & 0 \\
2 & 2 & 0 \\
1 & 2 & -1 \\
1 & 2 & -1 \\
3 & 1 & 2 \\
5 & 3 & 2 \\
\hline
\end{tabular}

b) After being recognized gap between occupational profiles with the employee profile, then we can plot or convert weights of each candidate applicants. Here is the conversion value of the weight of each applicant as listed in Table 4 below:

Table 4. Weighting prospective employees

\begin{tabular}{clccc}
\hline No & \multicolumn{1}{c}{ Selection Aspects } & Michae & $\begin{array}{c}\text { Retna- } \\
\text { ningsih }\end{array}$ & $\begin{array}{c}\text { Rayya } \\
\text { n }\end{array}$ \\
\hline 1 & Intellectual Intelligence & 1,5 & 2,5 & 3,5 \\
2 & Work Attitude Aspects & 1,5 & 1,5 & 1,5 \\
3 & Behavior and Personality & 1,5 & 4,5 & 5,5 \\
4 & Administrative Aspects & 1 & 12 & 1 \\
5 & Physical Aspects & 1,5 & 1,5 & 1,5 \\
6 & Verbal Aspects & 12 & 12 & 1,5 \\
\hline
\end{tabular}

In ranking the candidates, the formula that will be used are:

$$
\begin{aligned}
& \text { TN }=(x) \% \text { Nkc }+(x) \% N s k+(x) \% N p s+(x) \% N s a+ \\
& (x) \% N f s+(x) \% \text { Nvb }
\end{aligned}
$$

Where:

Nkc : The total value of intelligence criteria

Nsk : The total value of the work attitude

Nps : The total value of the behavior and properties criteria

Nsa : The total value of the administrative criteria

$\mathrm{Nfs} \quad:$ The total value of the physical criteria

$\mathrm{Nvb} \quad$ : The total value of verbal criteria

$(\mathrm{x}) \% \quad$ : Percent value is entered

TN : Total Value

As it is known in the findings, to the criteria of the standard norms of the company ( $\mathrm{kc}$, sk and $\mathrm{sa}$ ) each have a contribution percentage of $20 \%$ as it includes the core factor. Then (x)\% of Nkc, Nsk and the Nsa is $20 \%$. So, the 
core factor of three criteria accounted for $60 \%$ of the overall value of ranking the candidates. However, the criteria ps, fs and $\mathrm{vb}$ in which the needs of each partner is different depending on the type of positions are offered, the contribution percentage will certainly be different too. One moment we will see the needs of partners more likely to need a high physical values such as front liners, could be on the other side there is also a function that takes donations values higher than verbal such as call centers are required to communicate well. For that, we need a ranking back from three aspects, but here the author using AHP considerations are wise comparison of each aspect to the others. So, the percentage that will be produced will be better and more consistent.

c) Here are the stages of AHP applied by the authors to be able to show the percentage for the three secondary factor Pairwise Comparison by showing them as listed in Tables 5 and 6 below:

Table 5. Pairwise comparison

\begin{tabular}{lccc}
\hline \multicolumn{1}{c}{ Comparative } & $\begin{array}{c}\text { Behavior and } \\
\text { Personality }\end{array}$ & $\begin{array}{c}\text { Physical } \\
\text { Aspects }\end{array}$ & $\begin{array}{c}\text { Verbal } \\
\text { Aspects }\end{array}$ \\
\hline Behavior and & & & \\
Personality & $4 / 4$ & $4 / 3$ & $4 / 3$ \\
Physical aspects & $3 / 4$ & $3 / 3$ & $3 / 3$ \\
Verbal aspects & $3 / 4$ & $3 / 3$ & $3 / 3$ \\
\hline
\end{tabular}

Table 6. Pairwise comparison results

\begin{tabular}{lccc}
\hline Comparative & $\begin{array}{c}\text { Behavior and } \\
\text { Personality }\end{array}$ & $\begin{array}{c}\text { Physical } \\
\text { Aspects }\end{array}$ & $\begin{array}{c}\text { Verbal } \\
\text { Aspects }\end{array}$ \\
\hline Behavior and & 1 & 1.33 & 1.33 \\
Personality & 0.75 & 1 & 1 \\
Physical aspects & 0.75 & 1 & 1 \\
Verbal aspects & $\mathbf{2 . 5}$ & $\mathbf{3 . 3 3}$ & $\mathbf{3 . 3 3}$ \\
Total & & & \\
\hline
\end{tabular}

d) Proceed with the calculation of normalized as listed in Table 7 and as follows:

Table 7. Normalization

\begin{tabular}{lccc}
\hline Normalization & $\begin{array}{c}\text { Behavior } \\
\text { and } \\
\text { Personality }\end{array}$ & $\begin{array}{c}\text { Physical } \\
\text { aspects }\end{array}$ & Verbal aspects \\
\hline Behavior and & & $1.33 / 3.33$ & $1.33 / 3.33$ \\
Personality & $1 / 2.5$ & $1 / 3.33$ & $1 / 3.33$ \\
Physical aspects & $0.75 / 2.5$ & $1 / 3.33$ & $1 / 3.33$ \\
Verbal aspects & $0.75 / 2.5$ & & \\
\hline
\end{tabular}


Table 8. Normalization results

\begin{tabular}{lccc}
\hline Normalization & $\begin{array}{c}\text { Behavior } \\
\text { and } \\
\text { Personality }\end{array}$ & $\begin{array}{c}\text { Physical } \\
\text { aspects }\end{array}$ & Verbal aspects \\
\hline Behavior and & & 0.40 & 0.40 \\
Personality & 0.4 & 0.30 & 0.30 \\
Physical aspects & 0.3 & 0.30 & 0.30 \\
Verbal aspects & 0.3 & & \\
\hline
\end{tabular}

e) Having in mind the respective percentage of each aspect, then we can begin to calculate the Final Score each candidate by the formula, the calculation results are in Table 9 as follows:

Table 9. Total value calculation of the candidate results

\begin{tabular}{lcccccccc}
\hline \multicolumn{1}{c}{ Name } & Nkc & Nsk & Nps & Nsa & Nfs & Nvb & TN & Rank \\
\hline Michael & 1.5 & 1.5 & 1.5 & 1 & 1.5 & 12 & 2.66 & 2 \\
Retnaningsih & 2.5 & 1.5 & 4.5 & 12 & 1.5 & 12 & 5.54 & 1 \\
Rayyan & 3.5 & 1.5 & 5.5 & 1 & 1.5 & 1.5 & 2.44 & 3 \\
\hline
\end{tabular}

So, the results of these calculations, the candidate to the user in the user interview stage are as follows:

a) Retnaningsih (Priority).

b) Michael (Priority Backup).

\subsection{Testing Model}

Stages of testing carried out several stages as follows:

a) Validity Model as listed in Table 10 as follows:

Table 10. Validity Test Model

\begin{tabular}{|c|c|c|c|c|c|}
\hline \multirow[t]{2}{*}{ No. } & \multirow[t]{2}{*}{ Function Needs } & \multirow{2}{*}{$\begin{array}{l}\text { Subsystem } \\
\text { Module }\end{array}$} & \multicolumn{2}{|c|}{$\begin{array}{c}\text { Respondent } \\
\text { Answer }\end{array}$} & \multirow[t]{2}{*}{ Conclusion } \\
\hline & & & $\mathbf{S}$ & TS & \\
\hline 1. & $\begin{array}{l}\text { Managing Data } \\
\text { Applicants }\end{array}$ & Entry FLP & 9 & & Accepted \\
\hline 2. & $\begin{array}{l}\text { Managing Contracts } \\
\text { Umbrella }\end{array}$ & Entry PO & & 9 & $\begin{array}{l}\text { Do Not } \\
\text { Accepted }\end{array}$ \\
\hline 3. & $\begin{array}{l}\text { Managing Data Labor } \\
\text { Demand }\end{array}$ & Entry FPTK & 9 & & Accepted \\
\hline 4. & $\begin{array}{l}\text { Managing Data Results } \\
\text { of Walk In Interview }\end{array}$ & $\begin{array}{l}\text { Entry Form } \\
\text { Interview }\end{array}$ & 9 & & Accepted \\
\hline 5. & $\begin{array}{l}\text { Manage Data File } \\
\text { Selection Results } \\
\text { Administration }\end{array}$ & Upload CV & & 9 & $\begin{array}{l}\text { Do Not } \\
\text { Accepted }\end{array}$ \\
\hline
\end{tabular}




\begin{tabular}{|c|c|c|c|c|}
\hline & Managing Data & Posts & & \\
\hline 6. & Psychology Test Results & $\begin{array}{l}\text { Psikotest } \\
\text { Results }\end{array}$ & 9 & Accepted \\
\hline 7. & $\begin{array}{l}\text { Seeing The Results } \\
\text { Selection Candidate } \\
\text { Recommendation TMK }\end{array}$ & $\begin{array}{c}\text { See } \\
\text { Candidate } \\
\text { Recommen- } \\
\text { dation }\end{array}$ & 9 & Accepted \\
\hline 8. & $\begin{array}{l}\text { Managing Partner Data } \\
\text { (Supplementary) }\end{array}$ & $\begin{array}{l}\text { Partners } \\
\text { Entry }\end{array}$ & 9 & Accepted \\
\hline 9. & $\begin{array}{l}\text { Managing Data Function } \\
\text { (Supplement) }\end{array}$ & $\begin{array}{l}\text { Function } \\
\text { Entry }\end{array}$ & 9 & Accepted \\
\hline 10. & $\begin{array}{l}\text { Managing User } \\
\text { Interview Schedule } \\
\text { (Supplement) }\end{array}$ & $\begin{array}{l}\text { User } \\
\text { Schedule } \\
\text { Interview } \\
\text { Entry }\end{array}$ & 9 & Accepted \\
\hline 11. & $\begin{array}{l}\text { Managing User } \\
\text { Interview Results }\end{array}$ & $\begin{array}{l}\text { User } \\
\text { Interview } \\
\text { Entry }\end{array}$ & 9 & Accepted \\
\hline 12. & $\begin{array}{l}\text { May Viewed Candidates } \\
\text { Absorption } \\
\text { (Supplement) }\end{array}$ & $\begin{array}{c}\text { See } \\
\text { Absorption } \\
\text { Reports } \\
\end{array}$ & 9 & Accepted \\
\hline
\end{tabular}

b) Followed by functionality Test, Reliability, Usability, Efficiency Model as listed in Table 11 as follows:

Table 11. ISO 9126 Test

\begin{tabular}{lcccl}
\hline \multicolumn{1}{c}{ Aspects } & $\begin{array}{c}\text { Actual } \\
\text { Score }\end{array}$ & $\begin{array}{c}\text { Ideal } \\
\text { Score }\end{array}$ & \% Actual Score & Criteria \\
\hline Functionality & 315 & 360 & $87.5 \%$ & Very Good \\
Reliability & 185 & 225 & $83.1 \%$ & Good \\
Usability & 236 & 315 & $74.9 \%$ & Good \\
Efficiency & 162 & 180 & $90 \%$ & Very Good \\
Total & 898 & 1080 & $83.87 \%$ & Good \\
\hline
\end{tabular}

c) The final stage is to carry out the calculation of final test results by implementing the Forum Group Discussion (FGD) and the ISO 9126 test results as listed in Table 12 as follows:

Table 12. Test results

\begin{tabular}{clcll}
\hline No. & Mechanical Testing & Success & \multicolumn{2}{c}{ Criteria } \\
\hline 1. & Forum Group & $83,33 \%$ & Well Received & With \\
2. & ISCussion (FGD) & & Feedback & \\
\hline
\end{tabular}

Based on test results, the hypothesis in this study proved that the quality of the prototype model of decision support for User Submission Approval Energy 
Partners Candidate Profile Matching Method and AHP produced if measured in terms of software quality model of ISO 9126 achieve its original expectations is Good. The final result of the quality of the software according to the respondents is Good with the percentage of respondents amounted to $83.87 \%$.

\section{CONCLUSION}

Based on the results of the discussion above, it can be concluded as follows:

a. Making Decision Support Model for User Submission Approval Energy Partners Candidate Profile Matching Method and AHP conducted in the following manner:

1) The analysis with an emphasis on business procedures, review of documents and interviews.

2) The design is based on object oriented among the ERD database design, screen design with wire framing techniques, the order of access to the design sequence diagrams, class diagrams, design of access networks, and the design of the main conceptual models.

3) Preparation of the implementation plan.

b. Assessment of the implications of Decision Support Model for User Submission Approval Energy Partners Candidate Profile Matching Method and AHP method TELOS and PDM are as follows:

1) With the view of several factors model was developed with a base-line more appropriate order.

2) The efficiency value generated by over $100 \%$ for finance companies.

3) In the manufacture and operation of the model will not be caught by the copyright infringement cases or other criminal or civil case.

4) In the operation can improve the ability of users, data can be processed more leverage and the possibility of changing the standard operating procedure.

5) In the scheduling, team recruitment and selection can more easily access and manage data selection results are psychological test and interview user.

6) Employee productivity can be increased three times as productive as large and the company gets the opportunity to increase existing revenue.

7) Differentiation of business processes related to changes in the SOP, is job desk change, mutation, as well as individual work targets.

8) Generate new culture that accelerate the company's business cycle loop.

9) The feasibility of the model's overall score average of $83.87 \%$ for the four aspects tested.

\section{REFERENCES}


[1] K. Douglas Hoffman, John E. G. Bateson. 2001. Essentials of Services Marketing: Concepts, Strategies and Cases, South-Western.

[2] Nawawi, Hadari. 2000. Manajemen Sumberdaya Manusia Untuk Bisnis Yang Kompetitif. Yogyakarta: Gadjah Mada University Press.

[3] Bunawan, D. Suryadi H.S. 1996. Pengantar Metodologi Pengembangan Sistem Informasi. Universitas Gunadarma: Jakarta.

[4] Saaty, T.L. 2001. Decision Making For Leaders. Forth edition, University of Pittsburgh, RWS Publication.

[5] Dennis, Alan, et.al., 2009. Systems Analysis and Design with UML $-3^{\text {rd }}$ Edition, John Wiley \& Sons, Inc.

[6] R. E. Al-Qutaish. 2010. Quality Models in Software Engineering Literature: An Analytical and Comparative Study. Journal of American Science. 